\title{
The Full-Day Experience: Representing and Re-imagining Scotland in Online Narratives of the Film and TV Location Tour
}

\section{Petra Pugar}

\section{(2) OpenEdition Journals}

Electronic version

URL: http://journals.openedition.org/etudesecossaises/3643

DOI: 10.4000/etudesecossaises.3643

ISSN: 1969-6337

\section{Publisher}

UGA Éditions/Université Grenoble Alpes

\section{Printed version}

ISBN: 978-2-37747-275-8

ISSN: $1240-1439$

Electronic reference

Petra Pugar, "The Full-Day Experience: Representing and Re-imagining Scotland in Online Narratives of the Film and TV Location Tour", Études écossaises [Online], 21 | 2021, Online since 31 March 2021, connection on 31 March 2021. URL: http://journals.openedition.org/etudesecossaises/3643 ; DOI: https://doi.org/10.4000/etudesecossaises.3643

This text was automatically generated on 31 March 2021.

(c) Études écossaises 


\title{
The Full-Day Experience: Representing and Re-imagining Scotland in Online Narratives of the Film and TV Location Tour
}

\author{
Petra Pugar
}

\section{Introduction}

1 When considering the contemporary image-shaping of a nation's identity and its unstable facets in the perception of the widest population, what unfailingly comes to mind is the dominant role of TV and film within the global pop-cultural production. Entertainment industry and its reach, especially whenever possibly linked to lived spaces, are readily employed by the tourism industry, which today still uses text and narrative in order to create desire and promote directed consumerist human movement through space. These narratives, taking on contemporary forms, are propagated through online channels in order to reach the international traveller, and consequently take part in the construction of their experience. In a case study of touristic websites offering thematic tours that take place in Scotland and are based on presently popular TV-shows and series in some way or other linked to Scotland, this article will combine the approaches of (pop-)cultural, film and tourism studies with literary theory (namely critical discourse analysis, Scottish studies, narratology, and geo-criticism), to contribute to our understanding of the moving image and tourism and their influence on today's notions of Scotland and Scottishness. The first part will provide an overview of the main terms such as destination marketing, nation and representation (starting from literature as a predecessor and contemporary), including a brief history of the relationship between tourism and the moving image, while the second part will present a close reading of selected texts accompanying tours of the 
TV-series Outlander and films Harry Potter and Trainspotting, attempting to reach a wider conclusion on tourism and the contemporary vision-based imagined community.

\section{Tourism and the moving image}

2 The history of the relationship between tourism and the moving image has been previously widely studied in the field of tourism studies, where authors have employed a broad, interdisciplinary standpoint in order to encompass its unique position at the crossroads of various strands of human interest and activity (and non-human factors). Film- and TV-motivated tourism, along with literary tourism as its direct forerunner, is historically connected to the development of mass-produced long-distance transportation (Karpovich, 2010, p. 7). However, unlike its older counterpart, it has two especially pronounced elements that render it a human activity in its own right and worthy of separate consideration: movement ${ }^{1}$ and gaze. According to Karpovich, the latter has been given especial attention in scholarly analysis:

Urry (2002), Rojek (1997) and Jenks (1995), among others, have argued that the significance of visuality in contemporary culture far outweighs that of other types of perception, giving the pictorial representation (and in particular, the moving image) a primary role in shaping the modern tourist's expectations and perceptions of sights, and thus potentially producing in tours motivated by the moving image, a distinctly different experience than that of, for example, the literary tour. (2010, p. 9)

3 Karpovich emphasizes that both the moving image and tourism, based on spectatorship and technologies of movement, have been especially informed by America, whose role as a "cinematic country", in the words of Baudrillard, was crucial in the creation of the contemporary worldview through the cinematic lens. As such, this Hollywoodized tourism can be encountered throughout the literature in the subject under different terms, such as for instance "cultural tourism", "teletourism", "symbolic pilgrimage" or "popular media-induced tourism". ${ }^{2}$ This plethora of terms, indicating more or less the same subject, points to a less than intentional multidisciplinarity of research fields such as leisure and tourism studies on the one hand, and film studies, media studies, cultural studies and fan studies on the other, that unfortunately do not all readily exchange knowledge among each other. Their methodologies, Karpovich continues, differ as well, and are predominantly quantitative among the former (focusing on tourism policy, tourist numbers etc.) and qualitative among the latter. The present article sides with the qualitative approach in order to investigate notions such as creation of meaning and "authenticity" while looking at the subject matter's reflection on the concepts of space and nation.

4 Another term previously theorized within the study of film-motivated tourism is what Beeton calls "destination marketing through film" (2005, p. 43), constituting the framework within which all the texts analysed below are created. Although economically driven and stemming from conscious branding of a location, this strategical planning is, according to Beeton, one, but not the sole factor in the formation of a destination's image (ibid.). However, it is interesting to see how the conflation of capitalist and community interests, aimed simultaneously at the consumer, the investor and the native community, results in contributing to more than what we understand under the term "location branding". When approaching the multifaceted conceptualization of tourist location, we can observe the roles this 
conceptualization has taken on historically (not to imply any kind of teleology or positivist notion of progress) in order to consider its wider context and investigate how contemporary image production functions as opposed to its previous counterparts. A possible point of entry is the written word:

Most of the world's great pilgrimage and tourist sites were established through the written media, well before the coming of film, and this limits the effect that film had on actually establishing the iconic status of such sites. (Beeton, 2005, p. 4)

5 As we will see below, already at a first glance a continuity and influence of the Romantic notions of the picturesque is to some extent recognized in today's word written online, especially that which precedes and accompanies the touristic experience. This act of romanticizing was, according to Beeton, back then, but arguably today as well, especially valid for Scotland, the embodiment of rural and "natural" idyll in Victorian times $(2005$, p. 5$)$. Contemporary visuality retains some these transcendent components of the tourist gaze, "with rough bridges, sunsets, moonlight, cattle (seen from a distance), hedgerows and winding, tree-lined lanes being some of the desired elements" (ibid.), its function and contrastive potential updated in the age of technology and a reshaped urban experience, along with an updated concept of nation.

\section{Re-imagiNation of Scotland and Scottishness}

6 In the contemporary global context, the socio-political and cultural arena has been witnessing an overarching and widespread weakening of the nation-state. According to Hardt and Negri, this condition is characterized by its "declining sovereignty" and "inability to regulate economic and cultural exchanges". The new post-national apparatus expands frontiers by "manag[ing] hybrid identities, flexible hierarchies, and plural exchanges through modulating networks" (2000, p. XII). An ambivalence and formation of a particular community identity has remained ingrained in the Scottish experience. Early postmodernity, which was in Scotland marked by the failed devolution referendum of 1979, saw what Cairns Craig calls the "rise of 'alternative Englishes"' (1987, p.7) stemming from the decline of the British Empire, where separate national entities with their own cultures are largely taking the American example for emancipation. The term 'nation' in Benedict Anderson's definition, has had a rather distinct meaning in this particular context, with the United Kingdom originally "refusing nationality in its naming[, which] suggests that it is as much the legatee of the pre-national dynastic states of the nineteenth century as the precursor of a twenty-first century internationalist order" (1987, p. 2). Therefore, the political organization of the British Empire, and later the UK, arguably contained a potential for developing inter- and post-nations such as the community of today's Scotland, which in the 20th century was dominated by a "sense of impending extinction" (Craig, 1987, p. 1). Thus, the idea of civic and cultural nationalism (or culturalism) specific to the Scottish politico-cultural context is arguably different than some classic types of nationalism, being highly responsive and compatible with the tenets of postmodernity, but also with the disintegration of nations and their "postulates" in the early 21st century world dominated by extranational powers such as information, economic systems and technology, as well as human migrations. Diversity which includes a plethora of voices, becomes one of the tenets of Scotland's cultural nationhood, in the 
context where "hybridization of 'native' and immigrant cultures constantly redefines the nature of 'Scottishness"' (Niven, 2007, p. 320).

7 In order to see further how the elusive notion of Scottishness comes into play in this context, we have to observe the contemporary images of Scottish culture, changing notions of Scottishness and nation, created predominantly in the shared cultural experience through the workings of political reality and art. Pittin-Hédon (2018) gives an excellent overview of the problematics of representation and the role that (not necessarily high-brow) art, and literature in particular, plays in the reshaping of meaning of "nation" and "land". Pittin-Hédon recognizes the need to move away from the outdated concept of representation and go towards the re-imagination of the future, in line with Rancière's division of the subject and representation mode, calling to mind Scottish authors such as James Kelman and Alan Riach who express the need for the untying of art and politics in the sense of the ethical mode of images, aiming to avoid Scotland's reduction to tourist bait. This banalization, Pittin-Hédon claims, is exemplified in the "opposition to the management of the city of culture in Glasgow for reasons that partly had to do with the transformation of the event into a series of static images of Scottish culture" (2018). Before we see whether our case study texts move towards a similar goal, let us briefly discuss Riach's analysis of Scottishness in popular culture, this time in his role as literary scholar:

The history of the representation of Scotland and Scottishness in television and film presents innumerable examples of the crass cliché but it also reveals unexpected complexities. It is not defined by its medium. Film is not only film. Both the complexities and the clichés were developed from literary forms and work alongside and in dialogue with them. Film is literature. Scotland is the oldest of European nations and in the media made possible by modern technology, the nation remains a central question. (2005, p. 195)

8 Having this in mind, what are some key themes and images associated with Scotland in popular culture, moving beyond the usual tartanalia? Riach itemises them: the matter of voice; place (geography but also geology and landscape); nation and the "unfinished business of home"; language; people and finally, humour (2005, pp. 239-41). While these thematic areas are widely recognized and self-declared inside Scotland, studies in heritage tourism, especially the one linked to images created in contemporary film and TV, paint a different picture. Noorda's (2017) quantitative research of identity through book consumption among diasporic Scots reaches the conclusion that certain myths, symbols and traditions seen by the homeland Scots as inauthentic, are reinterpreted and revalorized by the diaspora through a sense of belonging to the ethnic community. Many interviewees mentioned the series Outlander, seen by the homeland Scots as a perpetuation of these myths, in the positive sense of self-definition and identity formation. Martin-Jones (2014), when looking at film tourism as heritage tourism, points out the same on the example of The Da Vinci Code and the changing role of Rosslyn Chapel, a setting resonating with heritage tourists with a sense of belonging. Static and symbolic images are therefore extracted and the notions of culturalism and cosmopolitanism that are of interest to Scots in Scotland do not seem to travel far, especially when the main means of communicaton is mass film production, more often than not from across the pond. Let us see how, and whether, this is reflected in touristic texts created in Scotland and aimed at the international traveller in general, not just the "heritage tourist". 


\section{Scotland, the film role}

9 In order to observe film-motivated touristic texts and their function in the construction of the national image of Scotland and Scottishness, the following close reading will focus on certain tours selected for two main criteria: that of prominence and that of their genre's reality-claiming level, assuming that a realist, pseudohistorical and fantasy programme will exhibit different manners of representation. Not every programme analysed here is aired at the moment, but all are among those whose presence in the touristic Scotland is the most pronounced at the moment of writing. ${ }^{3}$ For example, the Harry Potter films show a consistent popularity through time, especially among the Millennial generation that grew up with the books and the film series and continues to revisit it as grown up tourists.

As with the Harry Potter franchise, the other two focus programmes are adaptations of successful books, which adds another layer of connection to the inextricable role of literature and film to the context described above. The first one is the enormously popular Outlander series, which in recent years has dethroned all other Scotland-based narratives in terms of touristic consumerism. Let us start with a narrative analysis of its tour to see how the image of Scottishness is constructed in texts provided by various operators. Apart from the formulaic immersive phrases characteristic of any touristic text, such as "Are you ready to" or "Join us", and the reiteration of the Romantic and gothic legacy in the descriptions of the ruins ("atmospheric and formidable", "dank and despairing"), this example reads like an interesting blend of allegedly "real" history and fictional background:

Are you ready to visit the imposing ruins of Ruthven Barracks, where Charles Edward Stuart (Bonnie Prince Charlie) sent word to the Jacobite support that had congregated there in the immediate aftermath of the Battle of Culloden that the uprising was over, and that every man should "seek his own safety in the best way he can"? These atmospheric and formidable ruins demonstrate just how dank and despairing the 18th century military barracks were, as Jamie found out first hand during his imprisonment in Fort William! (Happy Tour, emphasis mine)

The seamless back-and forth narrative shifting between a description of a historical event (the aftermath of the Battle of Culloden) and the TV-show's protagonist taking part in its fictional re-enactment is historiographic metafiction in practice, exposing history as itself a story-construct, comprised of characters and a plot where the American novelist Diana Gabaldon easily inserted and blended fictional characters with the ones whose existence is supported by historical evidence. Although at first glance Scotland here features as itself, the role played by Scotland in the Outlander universe and the tour description as its paratext, is its own historical construct. The historical romance genre, permeated by elements of fantastic time-travel based on Scottish mythology surrounding standing stones, results in an image of Scotland as a place of the past, where tourists themselves can imagine stepping into:

You will step back in time with your guide as you make your way through the quaint streets which are protected by the National Trust for Scotland and retains many of the 16th and 17th features that make it so important to Scotland's past. (Slainte Scotland) [sic]

The interactive, immersive aspects of the tour reflect the romantic aspects of the show's genre, painting the tour's expectations in terms of the Scottish people as 
handsome and brave clansmen similar to the male protagonist: "Will you be Claire and find your own Jamie as we enjoy this Outlander tour from Edinburgh?" (Slainte Scotland)

On the other hand, there are tours that offer modified experience of typical historicalsite tours, using Outlander as bait and motivation for the tourist to visit Scotland. Such texts soon exit the immersive blend of history and fantasy and take on a discursively authoritative voice by mentioning the TV show as a side note:

This is your chance to learn more about the political landscape that Claire falls into when she travels back in time to 1743 , two years before the 1745 Jacobite Rising led by Bonnie Prince Charlie. As you explore Edinburgh's Old Town keep your eyes peeled for three key Outlander filming locations. [...] Located at the foot of the Royal Mile, the Palace of Holyroodhouse is an elegant royal residence with links to monarchs from throughout the centuries. Today it is the official Scottish residence of Her Majesty The Queen. (VisitScotland, "Tour Scotland with Outlander")

This is also an example of how the texts differ depending on the tour provider type. Dedicated tours made by fans and for fans have this reflected in the narrative as well, as we see in the following extract from a Harry Potter tour: "Prepare to enter a secret world... Grab a wand and join your robed guide on the original tour of Edinburgh designed especially for Potter fans!" (The Potter Trail)

With the Harry Potter franchise, we move to the realm of fantasy fiction, where Scottishness adds meaning with its sites paradoxically standing in for movie and book locations, creating an enhanced reality of the interactive, choose-your-adventure type. Tourists are again invited to take part in dress-up, and the location is given a set of expectations to meet, not as universally understood images available to all, but reserved for the ones with a "ticket" of having watched the related programme. Fans are in search of an unmediated experience, which they can re-mediate on their own smartphones, and the social media becomes part of creating the "shared representation":

[...] the touristic experience is thus bound up with representation and reproduction of the "original" sight through primarily visual means. The ultimately collective nature of the film/television viewing experience may contribute to giving filmrelated sites what Hayden (1995) termed the "power of place": "the power of ordinary urban landscapes to nurture citizens' public memory, to encompass shared time in the form of shared territory". (Hayden, 1995, p. 9, quoted in Karpovich, 2010, p. 9)

This brings us to the question of original, i.e. authenticity, which depends on various factors, hierarchies and understandings recognized in tourism studies. The authenticity and trueness of a location depends on the quality it purportedly intrinsically possesses. It can thus happen that a place deemed "inauthentic" by the standards of history, can be "authentic" in the sense of its corresponding representation on the silver screen, and in such cases "tourists are often more interested in experiencing what has been promoted through the powerful visual media than in gazing at so-called 'dead' history" (Beeton, 2005, p. 22). The example of the Wallace monument in Stirling, which "combines touristic markers from two distinct, but thematically related, realms (actual local history and its cinematic representation, which was actually filmed elsewhere)" (Karpovich 2012, p. 14) shows that the realms can co-exist in a location's claim to authenticity. In fact, cinematically authentic realms can alter the image of a place, not only for the international tourist, but also for the members of the imagined community, which according to Riach (2005, p. 195) happened with the rise of the SNP on the polls after the stellar success of Braveheart. 
Returning to the Harry Potter tour, its vocabulary certainly takes part in this construct, shaping the image of Scotland, where places receive different names and characterization:

\begin{abstract}
All aboard the Hogwarts Express /
Witness the sweeping cinematic scenery straight out of the eight blockbuster films by booking a seat on the Jacobite Steam Train, which travels from Fort William to Mallaig along the West Highland Line. Stop for lunch in Mallaig and then make the return journey to Fort William. [...] In the films, mysterious, misty landscapes frame the backdrop of Harry's tale, so it's no surprise that the producers chose the Highlands for many scenes. Spend a day wandering through some of these beautiful spots and feel the magical atmosphere. (VisitScotland, "Harry Potter Film and Book Locations Itinerary")
\end{abstract}

The Jacobite Steam Train is simultaneously Hogwarts Express, in the same way Doune Castle is a historical place in its own right, Castle Leoch from Outlander, Monty Python castle, Winterfell in the Game of Thrones pilot episode and more, showing how films, TV-shows have the power to give prominence to places previously uninteresting to the wider audience.

Let us now move from Scotland's castles, monuments and natural landscapes to the urban space of Edinburgh as depicted in the Harry Potter tours. Roberts, in his analysis of another urban space, that of Liverpool, looking at the cultural production of place, space and memory in the post-industrial city, focuses on what he calls cinematic geographies, applicable to the reading of urban space in general, especially when it is 'playing itself' or functioning as a 'body double':

[...] the term 'location' connotes not so much a specificity of place, history and local identity, as a rationalized economic resource. Viewed thus, the urban landscape functions as a production unit, harnessed to serve as a backdrop for narratives and geographies which have no necessary diegetic connection to the actual locations where the filming takes place (the 'taking' of place here also suggesting ideas of appropriation or annexation). (2012)

19 The spatiality of Scottishness thus comes to encompass the spaces of fantasy, adding visual material to the backdrop for a Potter-esque mood, even when the tour of Edinburgh bases its appeal of the visit on the fact that the city served as inspiration for the books, and was mostly not the actual filming location. Harry Potter's Edinburgh becomes a city with a "virtual geography", which raises "pressing questions as to the sustainability of post-industrial landscapes that are dependent on the increasingly nebulous spatialities of the film and cultural industries" (Roberts, 2012).

Seeing as in the tour narratives Scotland occupies various spatial roles, from a film background and setting to one of the main characters, a geo-critical analysis unravels the multiplicities of reading it: as a material physicality, as layers of (selected) historydiscourse, and as the various roles it plays on the silver screen through the touristic texts that stem from that type of representation or re-imagination. Henri Lefebvre (1996, p. 30) argues that social space is, instead of an empty container of thought, a social product enabled by human effort. According to Lefebvre, space is at the same time a social relationship, a means of production, and a product to be used, and the type of reality it occupies is both formal and material. If space is produced through spatial practice (the perceived space), representational space (the lived space, determined by politicians and architects) and representations of space (the conceived space and discourse on space) (ibid., p. 414), geo-criticism operates somewhere between the geography of the 'real' and the 'imaginary', and literature defamiliarizes these 
relations. Since previous literary studies, when talking about space, focused mostly on the relationship between subjectivity and so-called nature (which we know today is also a constructed dualist term), the imagined experience of the more or less real world, it is necessary to approach the production of real space through the inability of a direct approach to it, as it involves the physical body of the critic, the writer and the book as the artefact, located in space, which is not a given, but bordered by our interventions and gaze. The impossibility of getting a purely rational grasp of reality (always determined by spatial practices that include, for example, the instrumental mind) through mere reading and established theory when analysing, for example, city films and novels, brings us to the necessity to consider a geological, pre-human perspective and the transdisciplinary method of including geographical findings.

With this in mind, the question of urban spatial practices brings us to the final set: the Trainspotting tours. Their sphere of realism and social engagement, while sharing some of the abovementioned textual and destination marketing features (such as scene re-enactment), demonstrate some new moments in terms of Scottish identity formation, by connecting the space with the community. Discover Glasgow, advertising its tour pointing out the city as a "stand-in" film location, provides aural as well as visual motives in the introduction, calling into mind the cult status and pop-cultural context of the film:

Despite the majority of the film, based on Irvine Welsh's 1993 cult novel, taking place in Edinburgh, Glasgow was used for the majority of filming and many of the iconic scenes took place in the city. Traipse around town, revisiting the places visited by Renton, Sickboy, Begbie and Spud, with the likes of Born Slippy, Primal Scream and Iggy Pop and pulsating repeatedly in your ears. (Discover Glasgow)

Trainspotting-and the generation it fostered-add a layer to the experience of Scottishness that comes close to the kind of culturalism seen above in contemporary Scottish literature, combining the sense of the people and its social reality with the urban spaces of Scotland. More than any other tour location description analysed in this article, Leith Walks is the prime example of an alternative tour that steps away from banal Scottishness. In its claim of originality and authenticity, not as filming location (which is the title boasted by Glasgow), but as the depicted community that the tourist can come in contact with and take part in its re-imagination:

In Tommy's words “Doesn't it make you proud to be Scottish?" YES! Tim doesn't agree with Renton's answer ("it's shite being Scottish"). He is a Leith (honorary) native, social historian and knows Leith inside-out - the good and the bad. [...] Tim's Trainspotting Tours and the book, embeds him further in the fabric of an ever-changing, vibrant and dynamic Leith. [...] Tours can be customised as required; for example focussing on addiction, or HIV/AIDS, or the distinctive social/ community issues in Leith that gave rise to the Trainspotting generation. (Leith Walks)

23 Although this tour does not escape the methods of story-line and spatiality construction employed by such texts in general, it shows Scotland, as well as the quality of "being Scottish", as something possible to share in, far from the picturesque romanticized tropes of Outlander and fantastic background of Harry Potter; a de-centralized, struggling community affected with drugs and AIDS, keen on looking towards the transformative potential of a bright future, rather than stopping at representation. 


\section{Conclusion}

Having observed some narrative techniques, motives and features paid particular attention by online tour descriptions, particularly different ways in which they envisage their fictionality, historicity and spatiality using moving-image inventions, and having seen that the spaces in question locate the subject "both everywhere and nowhere" (Hardt \& Negri, 2000, p. 190) in "virtual non-places of deterritorialized power" (Roberts, 2012), it is important to recognize the discourse through which these online tour descriptions are created as narratives that not only "humanize urban built environments" (ibid.) but also others, so we can identify "natural" environments as perceived and constructed in storylines, and navigate their complexity. Offering the visitors interaction and immersion in the vision-based world of the moving image, recreating a secondary-world narrative within the physical space, the texts analysed above predominantly support the fixity of banal Scottishness; however, as we can see from the example of the Trainspotting Leith tour, they can also support the kind of culturalism often seen in contemporary Scottish literature. Between authenticity, cinematic geographies, consumer-focused logic and the representation of different levels of fictionality, this type of cultural discourse feeds into the globalized variety of possibilities of reading space. On the international viewer/traveller's journey that leads first through the consumption of the moving-image that uses Scotland as a theme or a setting, continues through the textual reiteration as seen in these tour descriptions, and reaches completion by visiting the spaces themselves and interacting with their virtual geographies, an image of Scotland and its identity is created that is both a fragmentary postmodern play and a continuation of some earlier historico-fictional tropes. Since the main force directing this image is consumer capitalism, all that is left to be seen is which of those will survive into the next generation. However it will be interesting for scholars to focus on the technologies of art and the entertainment industry, and the ways in which their consumers' needs and habits will be reflected-as well as affected-by the particularities of image-shaping paratexts.

\section{BIBLIOGRAPHY}

\section{Works cited}

ANDERSON Benedict, 2006, Imagined Communities. Reflections on the Origin and Spread of Nationalism [1983], London and New York, Verso.

BeETon Sue, 2005, Film-Induced Tourism, Clevedon, Channel View.

CRAIG Cairns, 1987, “Twentieth Century Scottish Literature: An Introduction”, in C. Craig (ed.), The History of Scottish Literature: Twentieth Century, vol. 4, Aberdeen, Aberdeen University Press, pp. 19. 
HARDT Michael \& NEGRI Antonio, 2000, Empire, Cambridge, Harvard University Press.

HAYDEN Dolores, 1995, The Power of Place: Urban Landscapes as Public History, Cambridge, MIT Press.

KARPOVICH Angelina I., 2010, "Theoretical Approaches to Film-Motivated Tourism”, Tourism and Hospitality Planning \& Development, vol. 7, no. 1, pp. 7-20.

LEFEBVRE Henri, 1996, The Production of Space [1974], New York, Wiley-Blackwell.

LURIA Sarah, 2011, “Spatial Literacies. Geotexts”, in M. Dear, J. Ketchum, S. Luria, and

D. Richardson (eds), GeoHumanities: Art, History, Text at the Edge of Place, London and New York, Routledge.

MARTIN-Jones David, 2014, "Film Tourism as Heritage Tourism: Scotland, Diaspora and The Da Vinci Code (2006)", New Review of Film and Television Studies, vol. 12, no. 2, pp. 156-77.

NIVEN Alastair, 2007, "New Diversity, Hybridity and Scottishness", in I. Brown, T. O. Clancy, S. Manning, and M. Pittock (eds), The Edinburgh History of Scottish Literature. Vol. 3, Modern Transformations: New Identities (from 1918), Edinburgh, Edinburgh University Press, pp. 320-31.

NooRDA Rachel, 2017, "From Waverley to Outlander: Reinforcing Scottish Diasporic Identity through Book Consumption", National Identities, vol. 20, no. 4, pp. 361-77.

PITTIN-HÉDON Marie-Odile, 2018, "Reconstructing the Future: Contemporary Scottish Literature and the Nation", Études écossaises, no. 20. Available on <https://doi.org/10.4000/etudesecossaises. $1416>$.

RIACH Alan, 2005, Representing Scotland in Literature, Popular Culture and Iconography: The Masks of the Modern Nation, Basingstoke and New York, Palgrave MacMillan.

ROBERTS Les, 2012, Film, Mobility and Urban Space: A Cinematic Geography of Liverpool, Liverpool, Liverpool University Press.

\section{Internet material}

"Harry Potter Film and Book Locations Itinerary", VisitScotland, n.d. Available on $<$ www.visitscotland.com/see-do/attractions/tv-film/harry-potter-itinerary/> (consulted Sept. 2019).

“Outlander Day Tour: Edinburgh", Slainte Scotland, n.d. Available on <slaintescotland.com/ outlander-tours/outlander-day-trip-edinburgh/> (consulted Sept. 2019).

“Outlander Highlands Tour", Happy Tours, n.d. Available on <happy-tours.biz/tours/outlanderhighlands-tour[...]> (consulted Oct. 2019).

“The Potter Trail", The Potter Trail, n.d. Available on <www.pottertrail.com> (consulted Oct. 2019).

“The Trainspotting Tour”, Discover Glasgow, n.d. Available on <www.discoverglasgow.org/ trainspotting-tour/4579879125> (consulted Oct. 2019).

“The Trainspotting Tour", Leith Walks, n.d. Available on <www.leithwalks.co.uk> (consulted Oct. 2019).

“Tour Scotland with Outlander", VisitScotland, n.d. Available on <www.visitscotland.com/see-do/ attractions/tv-film/outlander/itinerary/> (consulted Oct. 2019). 


\section{NOTES}

1. Both as transportation of people and movement of picture frames.

2. On these types of tourism and researchers using the respective terms, see more in Karpovich (2010, pp. 10-11).

3. The intention is to see which texts potentially reach the widest audience in order to make conclusions about cultural influence; although this is not a work of quantitative research, the selection was made using the same approach which would be employed by the Internet user, i.e. potential travellers themselves Googling "Scotland film tour", as well as the approach of capitalist logic: frequency of a certain tour among various tour operators is a marker of profit, that goes hand in hand with prominence in image-shaping.

\section{ABSTRACTS}

This article analyses how Scotland and Scottishness are represented and re-imagined in selected online texts aimed at international tourists visiting its castles, cities and landscapes that double as locations for the TV-series and films Outlander, Harry Potter and Trainspotting. In a dialectic relationship between consumerism, secondary-world building, spatial practices and concepts such as vision and authenticity, each particular moving-image genre is accompanied by a different set of images of Scotland brought forward in these texts, largely supporting the fixed representation of banal Scottishness and its romanticized tropes, with some exceptions that challenge these images and contribute to the type of culturalism seen in contemporary Scottish literature.

\section{INDEX}

Keywords: film-motivated tourism, touristic narratives, destination marketing, representation, authenticity, culturalism

\section{AUTHOR}

\section{PETRA PUGAR}

Petra Pugar is a PhD candidate at the University of Zagreb, Faculty of Humanities and Social Sciences, writing her dissertation in Scottish Literature. Her research interests include postmodern literature, eco/geo-criticism and convergences of visuality and narrative. In 2018, she was awarded the Saltire Scholarship to present at the Scottish Universities Summer School in Edinburgh, and in 2019 she received the AMAC-UK award to perform a PhD research project at the University of Glasgow. She is currently the Network Coordinator of the International Alasdair Gray Research Network and Organizing Committee member of the upcoming 2021 Alasdair Gray Conference. Member of The Croatian Association for the Study of English, The European Society for the Study of English, Association for Scottish Literary Studies and Croatian Literary Translators Association. 